Please do not remove this page

RMIT

UNIVERSITY

\title{
Wildlife gardening for collaborative public-private biodiversity conservation
}

Mumaw, Laura; Bekessy, Sarah

https://researchrepository.rmit.edu.au/esploro/outputs/9921860906701341/filesAndLinks?institution=61RMIT_INST\&index=null

Mumaw, L., \& Bekessy, S. (2017). Wildlife gardening for collaborative public-private biodiversity conservation. Australasian Journal of Environmental Management, 24(3), 242-260.

https://doi.org/10.1080/14486563.2017.1309695

Document Version: Accepted Manuscript

Published Version: https://doi.org/10.1080/14486563.2017.1309695

Repository homepage: https://researchrepository.rmit.edu.au (C) 2017 Environment Institute of Australia and New Zealand Inc.

Downloaded On 2023/04/27 00:07:32 +1000 
Thank you for downloading this document from the RMIT Research Repository.

The RMIT Research Repository is an open access database showcasing the research outputs of RMIT University researchers.

RMIT Research Repository: http://researchbank.rmit.edu.au/

\section{Citation:}

Mumaw, L and Bekessy, S 2017, 'Wildlife gardening for collaborative public-private biodiversity conservation', Australasian Journal of Environmental Management, vol. 24, no. 3, pp. 242-260.

See this record in the RMIT Research Repository at:

https://researchbank.rmit.edu.au/view/rmit:48265

Version: Accepted Manuscript

\section{Copyright Statement:}

(C) 2017 Environment Institute of Australia and New Zealand Inc.

\section{Link to Published Version:}

https://dx.doi.org/10.1080/14486563.2017.1309695 


\title{
Wildlife gardening for collaborative public-private biodiversity conservation
}

\author{
Laura Mumaw $^{1} \&$ Sarah Bekessy ${ }^{1}$
}

${ }^{1}$ School of Global, Urban and Social Studies, RMIT University, Melbourne, VIC, Australia

* Corresponding author: Laura Mumaw. School of Global, Urban and Social Studies, RMIT University, GPO Box 2476, Melbourne, VIC, 3001, Australia. Email: laura.mumaw@rmit.edu.au

The Version of Record of this manuscript has been published and is available in the Australasian Journal of Environmental Management on 10 Apr 2017

http://www.tandfonline.com/10.1080/14486563.2017.1309695.

\begin{abstract}
Complementary public and private conservation action is required to sustain native biodiversity in cities. Residents can contribute by wildlife gardening - removing environmental weeds, cultivating indigenous flora, and improving habitat in their gardens. There is currently little guidance about how best to involve residents in wildlife gardening and align their work with public land management. We explored how a purposively chosen wildlife gardening program in Melbourne, Australia engaged and supported residents to augment local government efforts to conserve indigenous biota. Sixteen semi-structured interviews were conducted with program members to understand the program's impact on their gardening and their connections with their council and community. Unpublished Council survey data were used to position interview findings on wildlife gardening activities and the value of program features. Interviewees detailed how they modified their gardening to assist their council to conserve indigenous biota. Five program features were implicated in this change: (1) on-site garden assessment; (2) indigenous community nursery; (3) communication hubs; (4) a framework that fosters experiential learning and community linkages; and (5) endorsement of each garden's potential conservation contribution. Collaborative wildlife gardening programs can engage residents to manage their land to achieve landscape-focused conservation goals while building relationships with council and community.
\end{abstract}

KEYWORDS: Urban biodiversity, nature conservation, wildlife gardening, environmental education, urban nature conservation, biodiversity conservation 


\section{Introduction}

As cities continue to grow exponentially, disrupting the native ecosystems in and around them (Lambin et al. 2001), there have been calls to develop the motivation and skills of urban residents to care for biodiversity (Secretariat of the Convention on Biological Diversity 2012). Engagement of this sort can lead to political and financial support (Dunn et al. 2006), conservation volunteering (Schwartz 2006), and improving habitat for native species on one's own land (Goddard et al. 2010). A comprehensive review of the urban conservation literature concluded that more research is needed about how to use urban green spaces, including gardens, to conserve biodiversity, and how to foster conservation behaviour by residents (Shwartz et al. 2014).

In cities, multiple strategies are needed for biodiversity conservation, including maintaining habitat patches and buffers, developing corridors and stepping stones, and improving the habitat quality of the matrix (Kowarik 2011; Threlfall et al. 2016). Complementary activities are required by public and private landholders (McCaffrey \& Mannan 2012; White et al. 2009). Local governments can protect and enhance native habitat on public land (Standish et al. 2013) and improve connectivity between these spaces (Rudd et al. 2002), including along streams and roadsides (Ikin et al. 2013; van der Ree 2009). Residents can augment these efforts, improving the landscape matrix by providing habitat for native species in their gardens, known as wildlife, habitat, or ecological gardening (Goddard et al. 2010; Lindemann-Matthies \& Marty 2013).

Wildlife gardening activities include removing environmental weeds (Smith et al. 2006), adding habitat features such as shelter or nesting sites and planting indigenous flora (Goddard et al. 2010), nurturing indigenous regrowth (Doody et al. 2009), and sometimes feeding birds (Goddard et al. 2013) although this practice can be detrimental to native species (Galbraith et al. 2015).

The potential of wildlife gardening to improve habitat for native species is substantial (Goddard et al. 2010), as residential gardens comprise a sizable proportion of land in many cities (Davies et al. 2009), and gardening is an activity that many diverse residents undertake. Maximising this potential requires engaging residents to wildlife garden, and aligning these practices with public conservation land management (Goddard et al. 2010).

There has been little empirical investigation of how to foster wildlife gardening effectively, or how to do so in a way that aligns this work with public land management. The aim of this study was to investigate how a purposively selected wildlife gardening 
program engaged and supported residents to augment Council efforts to conserve indigenous biota across the municipal landscape. We begin with a brief review of what is known about initiating and supporting wildlife gardening, and harnessing its potential for conservation.

\section{Engaging and supporting urban residents to garden for wildlife}

Little is known about the motivations for wildlife gardening (Goddard et al. 2013). Plant selection and husbandry are influenced by availability (Smith et al. 2006), aesthetics, functionality, ease of maintenance, attraction to wildlife, native-ness (Kendal et al. 2012; Uren et al. 2015), and a gardener's knowledge and experience with plants (Power 2005). Some of these factors (e.g. particular aesthetics) could hinder uptake of wildlife gardening while others (e.g. wanting to attract wildlife) could facilitate its uptake (Clayton 2007). The reported rewards of observing wildlife and taking care of living things (Clayton 2007; Freeman et al. 2012), including local wildlife (Bernardini \& Irvine 2007), could stimulate and reinforce wildlife gardening practices. Indeed, a study of British wildlife gardeners found that attracting or interacting with wildlife, particularly birds, was a key motivator (Goddard et al. 2013).

It has been postulated that pro-environmental behaviour derives from feelings of personal connection to and caring about nature (Nisbet et al. 2009), generated from interacting with local nature (Chawla \& Cushing 2007; Pyle 2003). Although appreciation for nature is a strong motivator for gardening (Clayton 2007), a strong sense of connectedness to nature (measured using a closed-question scale) is not required to engage in wildlife gardening (Shaw et al. 2013). Studies using closed-question scales have shown that having pro-environmental values does not predict wildlife gardening (Goddard et al. 2013) or correlate strongly with ecologically sustainable gardening practices (Larson et al. 2010). These results are ascribed to mediating factors such as social norms, pre-existing yard structure, and other motivations (Cook et al. 2012; Larson et al. 2010). Clayton suggested that it is because 'the garden seems to be seen as part of the domestic world ... rather than as part of wild nature' (Clayton 2007, p. 223), aligning with Bhatti and Church's (2004, p. 45) finding that gardens are valued most for making 'a house a home', and least for 'where you can care for the planet'.

Although many organisations in the UK, North America, Europe, and Australia promote wildlife gardening, little is understood of their effectiveness in engaging or sustaining people to do so (Nilon 2010; Shaw et al. 2013). Few studies have explored interventions that initiate wildlife gardening. Van Heezik et al. (2012) found that providing information to householders about native wildlife in their gardens while conducting biodiversity 
inventories there prompted some to wildlife garden. Cosquer et al. (2012) and Evans et al. (2005) reported that some citizen science participants began gardening to foster the wildlife they were monitoring in their gardens.

With so little investigated about initiating and supporting wildlife gardening, a nuanced exploration of how a program successfully engages and supports residents to remain involved in wildlife gardening is a core objective of this study.

\section{Integrating wildlife gardening into landscape scale conservation}

Effectively conserving species across urban landscapes requires action from a diversity of actors, including individuals and public bodies, with networks linking their activities (Ernstson et al. 2010). Suggestions have been made to increase and aggregate wildlife gardens using either 'top-down' regulation or financial incentives (Kirkpatrick et al. 2009), home-owner associations (Lerman et al. 2012), and community or non-governmental organisation-driven initiatives (Goddard et al. 2010). We wished to explore not only how a program can engage residents to wildlife garden, but also to do so in order to assist council as a form of public-private conservation land management.

\section{Methods}

We chose Knox City's Gardens for Wildlife (G4W) program (Knox City Council 2016) as a 'revelatory' case study (Yin 2003, p. 42), one that provided an opportunity to explore the dynamics of a collaborative wildlife gardening program in real life. Our primary data, obtained in 2014, came from semi-structured interviews with 16 G4W members. This study received ethics approval from a sub-committee of the RMIT University Human Research Ethics Committee.

\section{Case study program}

The Knox G4W program is located in outer eastern Melbourne. It is a collaboration between a community group - Knox Environment Society (KES) - and an urban council (Knox City) that promotes wildlife gardening (in this case removing environmental weeds, planting and protecting indigenous vegetation and vegetative structure, and providing habitat for indigenous wildlife) to help conserve the municipality's indigenous biodiversity (Knox City Council \& Knox Environment Society 2008). KES promotes the local environment and runs an indigenous plant nursery that is a key feature of the program. Since its beginning in 2006, G4W has been expanding, with no advertising investment, at between 50 and 70 new members a year since 2009. It currently has a membership of over 700 households. Knox City has a high proportion of indigenous 
species (Lorimer 2010) and garden character similar to Anglo colonial cities in North America and Australasia (Ignatieva \& Stewart 2009).

G4W members are residents of Knox City who join G4W simply by signing up online or by post. Members receive an on-site garden visit by garden assessors who explain the program's purpose, identify environmental weeds and indigenous biota in the garden, and describe specific opportunities for wildlife gardening. Members then receive an illustrated assessment report, a G4W booklet (Knox City Council \& Knox Environment Society 2008), and free vouchers for 20 KES nursery plants. Members whose property is deemed by council staff to contain habitat of sufficient quality and proximity to a conservation-significant site are invited to apply for a grant for their wildlife gardening activities (entailing an initial on-site planning visit and a post-completion review). Three to six newsletters are sent to members and posted on Council's website each year. Members also receive invitations to three to four program events that vary year to year, e.g. wildlife information sessions, open-garden days and visits to local reserves. In December 2012 G4W started a Facebook page to enable and stimulate members to communicate with and support each other virtually. Members can request advice or subsequent garden assessments from Council.

\section{Sampling strategy}

We sought to qualitatively explore, in depth, the impact of the program on a heterogeneous sample of G4W members, rather than to quantitatively assess a representative sample of G4W members. We obtained the assistance of 13 garden assessors (Council staff and G4W volunteers), who between them had visited over 200 members' gardens. In a group interview, these assessors identified different membership attributes based on their interactions with members, and then independently suggested potential interviewees they felt demonstrated a variety of these characteristics. All 32 members suggested in this way were invited to participate; 10 responded and were interviewed. Subsequently, the program coordinator invited 106 members on the membership database from across joining years and postcodes; six of these responded and were interviewed. While this indicates strong bias towards members willing to be interviewed, the sample was deemed suitable for the exploratory purposes of the research because (1) the sample was diverse (Tables 1 and 2) and (2) saturation, described by Guest et al. (2006, p. 65) as 'the point in data collection and analysis when new information produces little or no change to the codebook', was reached after 16 interviews.

\section{Data acquisition}


Data from interviewees and about their gardens were acquired through: (1) a short demographic questionnaire; (2) semi-structured interviews at interviewees' homes that included a walking tour of their gardens; (3) observations of the garden at interview; and (4) web and document review (Lorimer 2010) to obtain property size and proximity to parks and reserves. The demographic questionnaire was distributed to interviewees in advance, and collected at the interviews. It contained questions including interviewees' gender, age, employment status, qualifications, birth country, postcode, and years at the address.

We used interviews as the primary source of data because this method elicits a finer-grained understanding of how gardening attitudes and behaviour change than survey methods (van Heezik et al. 2012). The interviews were semi-structured and explored interviewees' gardening experiences, interaction with the program, and its impact on their gardening and social connections. Interviews varied from 45 minutes to two hours.

\section{Analysis of interview data}

We analysed interviewees' narratives inductively (Bryman 2012, pp. 384, 404) and compared our findings with recommended conservation engagement interventions. Transcripts were coded line by line using QSR NVivo for Mac. Codes were not pre-established, but derived from interviewees' responses. Enough narrative was coded to provide a context for each coded topic; if interviewees covered a number of topics in a single response these were all coded separately with different contextual segments as appropriate. Codes were grouped or merged into 'mother' nodes and finally 'master' categories as part of a fluid, inductive analytical process (Thornberg \& Charmaz 2011, pp. 41-51). The five master categories contained codes relating to: (1) the period prior to an interviewee commencing wildlife gardening; (2) the period after commencing; (3) interviewees' interactions with and opinions about the program; (4) interviewees' affective connections with items; and (5) interviewees' views on conservation of urban native biota. Memos were written throughout the coding and analytical process about patterns that were emerging and their interpretation.

\section{Alignment of interview, demographic, and property data}

Demographic data, property location and size, and summary information on interviewees' gardening experience, activities, and reasons for joining the program were uploaded into an Excel spreadsheet. Sortable columns were used to detect relationships between factors and compare responses between interviewees (e.g. Tables 2 and 3). 


\section{Positioning interview findings in relation to G4W member survey data}

We used responses to a G4W member survey, designed and conducted by Knox Council in 2009 to assess success of G4W and potential improvements, to provide some reference points for comparison with the interview findings. Although the data sets were collected at different times, key program features were the same over the period, with the exception of a Facebook page added in December 2012. The Knox Council survey contained both closed and open-ended questions, including several about members' wildlife gardening activities and the usefulness of G4W program features. Ninety-four members responded, representing a 42 per cent response rate. The data included no identifying information so we do not know whether the three of our interviewees who were in the program at that time participated in the survey.

Interview responses were compared with the survey responses for any commonalities or notable differences at several reference points. One group of reference points involved survey responses to closed questions about whether respondents had planted indigenous species or removed environmental weeds, and whether the garden assessment was useful. The other group of reference points involved survey responses to the open-ended questions: 'garden assessment comments', 'what has been the most useful part of the program', 'what has been the least useful', 'can you suggest any further improvements for the program', and 'further comments'. To facilitate this comparison, responses to the open-ended survey questions were coded in NVivo for Mac. Coded segments were placed in one or more relevant topical categories. This simple categorisation assisted a high-level review of the range of topics covered by survey respondents and ready reference to detailed comments in each topic area.

\section{Results and discussion}

In the presentation of results, pseudonymic initials are used for interviewee quotes. No identification is possible for the results of the Knox Council survey.

\section{Interviewee characteristics}

Interviewees were diverse in gender, age, educational qualifications, employment status, country of origin, postcode location, lot size, years at the property, and years in the program (Table 1). Interviewees' gardening experience prior to joining G4W also varied. This was grouped into four categories - inexperienced (two interviewees), backyard (four interviewees), traditional (three interviewees), and wildlife (seven interviewees) - see Table 2. 


\section{Effect of personal and situational factors}

Age

While some interviewees believed that age restricted (or could potentially restrict) their ability to perform arduous gardening tasks, this did not deter them from wildlife gardening. If garden size and topography posed challenges, interviewees still applied program recommendations although sometimes at a slower pace.

Prior gardening experience

Interviewees' gardening background prior to joining the program influenced why they joined, but generally not their uptake of program recommendations. A notable exception was three interviewees who had established a strong attachment to their gardening style and garden's form (they had all developed their gardens for over 20 years). One, with wildlife gardening experience, intensified her wildlife gardening activities, extending them into her nature strip. The other two, traditional gardeners, restricted their wildlife gardening to specific areas of the garden but still wanted to contribute, as I10 explained 'the indigenous [plants] ... are the ones that actually belong here. I'm not willing to give up all the rest but ... I think it's important to make some connection with the land, you can't just take it'.

Wildlife in the neighbourhood

Interactions that interviewees had with wildlife in the immediate neighbourhood and at home stimulated their interest in joining the program and were a source of ongoing motivation and satisfaction. These interactions related to the proximity of their gardens to reserves and the presence of particular species in their neighbourhood.

\section{Reasons for joining}

Interviewees learnt about the program through various channels including neighbours and friends, local paper, Knox Council's website, mail or seminar, exhibition stall, or the KES nursery. The majority were not actively seeking information about the program or wildlife gardening when they learned about it.

Table 2 presents the reasons interviewees provided for joining G4W. These predominantly related to advancing their gardening knowledge and intent. Having an interest in gardening is a key indication for joining. Nine of the 16 interviewees were interested in helping or attracting wildlife when they joined. It is striking that of this 
group, those interviewees without previous wildlife gardening experience (I13, I11, I15) all described having had moving interactions with wildlife in their gardens or neighbourhood. Encounters with wildlife are known to stimulate interest in their care (Ballantyne \& Packer 2011). I15 explained 'we saw the little echidna running around and lizards ... the whole thought process [about gardening] changed', while 111 said 'we used to get a couple of king parrots ... and there's this little echidna ... we just want to get them back'. Notably, only interviewees with prior wildlife gardening experience and intent $(11,12,13,15)$ joined for free plants or grants.

Another common reason for joining was interest in planting native species, given by all seven interviewees with prior wildlife gardening experience; one traditional gardener was interested in them as different plant material. Obtaining gardening advice was another common reason, particularly for those without wildlife gardening experience.

There was not a strong drive to wildlife garden to support the 'environment' in the broadest sense of the term. Two interviewees without wildlife gardening experience provided this reason, as 112 explained, 'There was no one trigger ... if it was needed for the environment, I was happy to try it'.

Three interviewees with previous wildlife gardening experience joined to support the G4W program and its focus on local species.

I thought it was just a really cool initiative from the Council and KES ... And I believe in what they're doing. Like getting enough trees ... it means powerful owls and the tawny frogmouths and possums actually have somewhere to live and it cools properties as well. (14)

\section{Program impact on wildlife gardening activities}

Table 3 shows the wildlife gardening activities interviewees had undertaken in relation to their prior gardening experience and years in the program. Critically, all had planted indigenous species and all but one had removed environmental weed species as a result of the program, regardless of years in the program or prior gardening experience or intentions. The high reported rate of wildlife gardening activities by interviewees aligns with results from the 2009 survey. All but two respondents answered the question about planting indigenous species; of these 96 per cent reported doing so. All answered the question about removing environmental weeds, and 88 per cent of respondents reported doing so. 
The extent and range of interviewees' wildlife gardening activities were not related to length of time in the program or prior gardening experience. A few interviewees without experience began with spurts of intensive activity fired up by newfound enthusiasm; for others, newly arrived children or domestic responsibilities reduced time for gardening. Those who had received grants (shaded in Table 3) said it helped them tackle costly or challenging activities earlier, particularly weed tree removal. Grant recipients undertook comparatively more (and diverse) activities than non-recipients, probably due also to the size and location of their properties (e.g. supporting large trees or self-seeding indigenous species).

Interviewees most readily adopted wildlife gardening practices that met their gardening preferences, which aligned with preferences reported in the literature, e.g. using plants with aesthetic qualities, survivability, functional traits like provision of shade or screening, or ease of maintenance (Clayton 2007; Kendal et al. 2012). Interviewees willingly planted indigenous species, particularly for screening, drought resistance, and to attract wildlife. This aligns with findings that the uptake of promoted conservation practices improves if they are compatible with a landholder's existing management practices (Pannell et al. 2006; Race et al. 2012). Some planted indigenous species that were locally endangered to assist in their conservation. A number maintained mature gum trees and if they had to prune them for safety, were retaining trunks and adding nest hollows. Interviewees welcomed the program's approach of letting them choose the pace and extent of their planting and weed removal activities. Some were delaying removal of weed trees until they could implement alternative privacy measures.

Interviewees wished to maintain good neighbourly relations. They had mixed views as to whether their activities influenced their neighbours' gardening. Interviewees felt free to wildlife garden even if neighbours gardened differently but were sensitive to their concerns. One interviewee with large gum trees close to the property line kept her neighbour informed about their health. Another reluctantly agreed to remove a large gum tree on the edge of his property at a neighbour's insistence. From interviewees' feedback and the researcher's observations of neighbouring gardens there was no evidence of 'gardening contagion', as also found by Kirkpatrick et al. (2009).

All interviewees intended to wildlife garden in the future, at current or future properties. Visible evidence of their commitment over previous months or years was present in the indigenous plants and potted tube stock in their gardens.

\section{Program impact on gardening purpose}


All but one of the interviewees reported that their gardening purpose was to help support or attract the indigenous biodiversity of Knox. This also emerged in comments of some survey respondents, for example, 'to care for my garden in a manner which provides for the local creatures from bugs upwards'. The one exception had not had a garden assessment yet and did not express awareness of indigenous species. A few interviewees and survey respondents spoke of helping to propagate or nurture rare indigenous species:

In my front garden there is a little plant there, it's a silver banksia, and I got it from KES, and apparently they're having trouble propagating it ... I said if I get any seeds, I'll make sure I gather them and return them to you. (I12)

Most interviewees felt their wildlife gardening was helping Council to achieve its conservation objectives, e.g. removing environmental weeds in their gardens so they would not infest Council reserves, planting rare indigenous species from the nursery, or retaining self-spreading indigenous species such as Gahnia sieberiana that support the locally threatened indigenous butterfly Tisiphone abeona albifacia. Interviewees appreciated Council's environmental efforts but felt it could do more: to improve the habitat quality of reserves, roadsides, and median strips; to promote and support the G4W program; and to involve their neighbours, particularly in removing weeds. Many expressed irritation that Council was planting the weeds they were removing from their gardens. 19 noted 'at the same time here's the Council planting rows and rows of agapanthus [a local environmental weed]. They are a menace'. This program-stimulated desire of residents for Council to play its role in helping them to improve habitat across the landscape demonstrates an incipient aligning of public and private land management for conservation.

\section{Key program features}

There were few criticisms of the program, either by interviewees or the Knox Council survey respondents. Only 56 per cent of the latter replied to a question about 'the least useful' part of the program, of whom 71 per cent gave answers like 'nothing' and 'it's all good'. Of the remainder, half wanted more information or resources and the others had a variety of minor complaints. A few interviewees wanted more visits or free plants while acknowledging resource limitations. Various program features supported the development of interviewees' wildlife gardening practices as part of a collaborative land improvement initiative with Council and KES. This commenced with discovering the indigenous biota and conservation potential of their gardens during the garden 
assessment and continued with the support of a framework that guided and reinforced their wildlife gardening activities.

On-site garden assessment

All interviewees who had received a garden assessment found it useful. Similarly, all 2009 survey respondents replied, with a 'yes', to the open-ended question of whether the garden assessment was useful. A number of interviewees reported that the on-site assessment elicited and reinforced a desire to attract or support wildlife. Some indicated that this resonated more strongly than an appeal simply to use indigenous plants: 'If they had said "plant these because they're good for Knox, but they're not going to attract the birds ... ", I probably would have said "phhhh, l'll get a tractor in and make it a lawn"' (113). Interviewees and survey respondents described the assessors as experts, helping them to see their garden in a different way, to discover its indigenous species and conservation potential. All interviewees indicated that without the program they would not have known about or fostered indigenous species, removed environmental weeds, or appreciated which of them were in their gardens. For most this recognition first occurred at the garden assessment: 'they were all walking around out the backyard, "Ooo, look at this," "Oooo, look at this." And I go, "Those things? I poison those"' (I13).

The assessment has the qualities of various factors reported to stimulate pro-environmental behaviour change: a 'change moment' with 'trusted others' (Robinson \& Glanznig 2003, p. 37), tailored advice (Snep et al. 2016), arousing emotions (Oskamp 2002), providing role models (Steg \& Vlek 2009), enhancing environmental conceptions through experiential impact (Ballantyne \& Packer 2011), and a 'free-choice, self-motivated learning environment' (van Heezik et al. 2012). Interviewees and survey respondents praised the assessment as one of the best elements of the program. They highlighted the supportive approach and expertise of the assessors, the clear and comprehensive advice and follow-up report, individualised attention, provision of ideas and options not directions, and the introduction to the nursery with vouchers for 20 free plants.

Hubs for personal advice and materials

Personal advice and face-to-face encouragement reinforced interviewees' interest, confidence, and motivation to continue. These interactions were highly valued and desired, in the way extension officers are by rural landholders involved in private land conservation (Pannell et al. 2006; Race et al. 2012; Selinske et al. 2015). Selinske et al. (2015) reported that interactive shared learning with an extension officer was the most 
powerful driver of landholder satisfaction with a conservation program. Interviewees who received grants valued the visits of Council officers as much or more than the material support. One explained 'they've [Council officers] been really, really helpful because you sort of struggle along ... every time they come out, we walk around the garden and say, "Now is this a weed" or "What's this", and they're really good' (I6).

For most interviewees, visits to the nursery provided face-to-face advice after the garden assessment. The KES nursery is critically important, not only for making indigenous plants available inexpensively, but also as a hub of advice and inspiration when needed, vital given the stop-start nature of gardening. All interviewees had visited the nursery and appreciated it: 'I know that I have a place to go if I ever need something' (I16).

Interviewees also appreciated Council's administrative unit as an information and support hub. Some sought advice via phone or other Council communication media, including a Facebook page, website, and newsletters. Some had contributed to these with posts or articles. 115 described a time when 'I have no idea what to do ... So I posted a picture through the program on Facebook. And I was getting an immediate response back, which was ... incredible.' 15 explained:

I do enjoy their website ... If you're straying off the philosophy of the Gardens for Wildlife then you can refresh your memory a little bit and say 'Ah, okay. Forgot about that. I've got to go back and do that'.

The interaction available, whether face-to-face or through other media, not only provides situational prompts (Werner 1999) and social support (Oskamp 2002), but also reinforcement that others in the community and Council care about their gardening.

\section{Experiential learning}

The importance of learning by doing is widely reported in pro-environmental behavioural change (Werner 1999) and conservation practice literature (Pannell et al. 2006). While not all interviewees could see the impact of their gardening in the appearance of more or particular wildlife in their gardens, they could see results in plants growing or weeds gone, as 12 described: 'Yeah success for us was having a clear patch.' Observable results help them persevere, another well reported adoption factor (Davidson 2012; Pannell et al. 2006). Another interviewee related: 
I was introduced to the whole idea and then, because I had some plants that worked and then some more plants that worked, then it seemed like a good idea and they managed to live through the drought $\ldots$ and it did noticeably make a difference with the amount of insects. (I10)

The increased skills and confidence interviewees gained from their experiential learning reinforced their motivation to continue. 15 noted, 'And we feel now more competent in this field than we did before. And our success rate seems to be improving. Yeah. So it's a very positive feeling to be acquiring a skill almost.' 14 was transplanting indigenous orchids he had discovered growing in the lawn of his previous property. He explained how he had discovered them, concluding with '[l] let them grow up ... Because we left there they're mowing over them again so luckily we took these specimens.' Some expressed learning itself as a reward: 'That's the best thing about gardening, you're just learning the whole way along' (I12). This is similar to how some of Bernardini and Irvine's (2007) participants described their gardening as a dynamic, rewarding process in which they engaged with nature, faced challenges, and experimented, thereby improving their knowledge of their garden and nature.

\section{Working in a collaboration}

Interviewees and survey respondents expressed connections with G4W members, Council's G4W arm, and KES as a result of participating in the program. Most interviewees reported that their connections with Council had improved although in relation principally, and sometimes only, to the G4W program and staff. A common sentiment was, 'I think the program's terrific ... So that gives me a good feeling about Knox Council even though I think they probably need to do something more with the program' (I2). Interviewees also spoke glowingly of KES and the KES nursery - not only for its indigenous plants, but also for the inspirational qualities of its volunteers, and for linking them to people with a shared environmental stewardship ethos. I12 explained 'if you're there at KES buying plants, you're rubbing shoulders with other people who are doing a similar thing'. I3 was even more inspired:

I just get a buzz out of going down to the indig [indigenous] nursery ... it makes you feel good about your neighbourhood and the people around and it's not all bad and the world's not bad. There's people that are doing the positive things.

While interviewees did not seek out social interaction with fellow G4W members, most felt a positive connection with them as fellow residents engaged in the same conservation effort: 'I feel good that there are more and more people joining, yeah, 
because that means there are more and more people getting rid of environmental weeds in the garden' (I1). Several survey responses expressed similar positive connections, for example that the most useful part of the program is 'a sense that others are also working to improve the situation for our wildlife'. Unlike the interviewees, some survey respondents had asked for more face-to-face social interaction, suggesting group visits to reserves and open-garden events.

\section{Endorsement of conservation purpose and value}

In all its communications, the program articulates that the goal of residents, Council, and KES is to care for indigenous species. Evidence that other G4W members, KES, and Council are doing so - through newsletters, Facebook posts, events, and the nursery - reinforced the sense of conservation purpose and contribution interviewees felt about their wildlife gardening. For grant recipients, the grants and field visit discussions provided tangible evidence that their land improvements have conservation value. This sense of purpose was also expressed by some survey respondents, for example in response to the most useful part of the program 'feeling that we are doing something perceived to be useful and that there are others doing the same'. We emphasise the importance of conservation endorsement for two reasons: the conservation value of urban gardens can be contested (Shwartz et al. 2014) and the promotion of wildlife gardening is more frequently conducted as education rather than collaborative municipal conservation (Nilon 2010).

\section{Implications for managing urban landscapes}

The capacity of an urban community to solve problems (in this case conserve indigenous biota) and maintain well-being lies in its individuals, formal organisations, relational networks linking them to each other, and the broader social systems of which they are a part (Chaskin 2001). If the desired outcomes are ecological in nature, the scale of the social and ecological processes need to align, requiring social networks between governmental agencies and community groups to address issues at a landscape scale (Ernstson et al. 2010). Preferably, individuals and communities should participate, working with public agencies to learn about, share knowledge, take responsibility for, and participate in collaborative environmental decision-making (Berkes 2004; Carter \& Ross 2012) and through the process, develop a shared language and values for conservation management (Norton 2005).

The G4W program involved members in improving habitat for indigenous biota by removing environmental weeds and planting indigenous species, including rare and endangered ones that the nursery had propagated, on their properties. Members did 
this to complement Council's conservation activities, particularly of developing stepping stones and corridors, and reducing weed load in bushland patches and buffers. These are well-recognised conservation strategies to improve habitat quality in modified, fragmented landscapes (Bennett \& Saunders 2010).

One possibility missing from this program is a system for Council, KES, and G4W members collectively nominating conservation species and targets, sharing learning, monitoring results, and adjusting plans accordingly. None of the interviewees had ecological or scientific expertise; they felt they had limited understanding of what ecological contribution their gardening was making. Assessing the ecological impact of their gardening activities remains a challenge, with immense temporal and spatial complexities. However, all interviewees were willing to help by providing feedback on their gardening activities, flora, and fauna in a form of citizen science.

Harnessing the potential contribution of wildlife gardening programs to biodiversity conservation in cities requires understanding their socio-ecological impact and ways to measure it, their applicability in other communities, sustainability, and scalability. All interviewees intended to wildlife garden in the future, a promising indication of the behaviour's sustainability. However, interviewees indicated that their involvement is supported by ongoing access to personal advice, inspirational program members, reminders of wildlife gardening practice, and acknowledgment that their contribution is important. Scaling up need not be just a numbers game. If, as this study indicates, residents can be engaged to collaborate with public land managers to support targeted flora and fauna, then action, including grant funding, can be strategically targeted in locations and ways that improve habitat for particular species. And if residents who experience wildlife are more readily engaged to manage their land to support local flora and fauna - as these members were - then involving urban residents living close to habitat patches and wildlife corridors may become progressively easier as habitats are extended and charismatic species spread their visits.

These findings are probably most relevant in situations similar to this case study: urban areas in developed countries hosting native flora and fauna. Next steps include quantifying findings across the G4W membership, assessing their validity in other scenarios, and evaluating the efficacy of the program in conserving targeted species. We also recommend exploring the inclusion of a participatory monitoring and evaluation component in wildlife gardening programs and opportunities for strengthening a collaborative governance and adaptive management approach. Significantly, the approach and features of the case study program are pragmatic and implementable. 
They show promise as a way to engage urban residents with public land managers to conserve biodiversity across a municipal landscape.

\section{Conclusions}

Wildlife gardening programs can engage a diverse group of residents to manage their land for the purpose of helping their council and community conserve indigenous biota, doing so in a way that aligns their efforts with those of council. This includes residents without prior intention or knowledge of wildlife gardening.

Participants in this study were stimulated to begin wildlife gardening by an on-site garden assessment that provided new understanding of their garden's biota and stewardship potential, along with personal advice and encouragement. Interviewees' interest in and continued wildlife gardening was supported by ongoing availability of indigenous plant species and advice and encouragement through Council and KES physical and digital hubs. Evidence that interviewees' gardening is making a valuable contribution to a Council-community conservation initiative is important to reinforcing their continuation, as are the rewards of gaining new knowledge and competence, and experiencing nature. While the survey data could not speak to this process and relationships, it did underscore the importance of the on-site garden assessment and its qualities, and the widespread involvement of G4W members in removing weeds and planting indigenous species. The survey responses also included similar comments to interviewees about the impacts of G4W on their gardening, support for indigenous species conservation, and connections with Council, other members, and KES.

The study shows that wildlife gardening programs can build relationships between councils, community organisations, and residents around shared, landscape-oriented conservation goals. These networks show promise as an incipient platform for improving the quality of native biodiversity habitat across a municipal landscape by engaging private and public land managers to work together towards that aim. Successful features of Knox gardening for wildlife program include: (1) on-site garden assessment; (2) an indigenous plant nursery hub; (3) visible involvement of council and community; and (4) a locality-based framework that encourages learning by doing and endorses the value of each garden's conservation contribution. We have demonstrated here that involving residents in wildlife gardening offers an opportunity to increase community support for conservation and to improve the habitat quality of residential land in cities.

\section{Acknowledgements}


The authors are grateful to Dr Cecily Maller for her valuable guidance and contributions to this study and manuscript, and to two anonymous reviewers whose constructive feedback has greatly improved the article. The authors sincerely thank the staff of the City of Knox, members of the Knox Environment Society, and participants in the Knox Gardens for Wildlife program who generously contributed their time and ideas for this research as interviewees. This research was conducted with funding support from the National Environmental Science Program (NESP) and the Australian Research Council Centre of Excellence for Environmental Decisions [grant number CE11E0083]. LM is supported by an Australian Postgraduate Award (Australian Federal Government) and SB is supported by an Australian Research Council Future Fellowship [FT130101225].

\section{References}

Ballantyne, R \& Packer, J 2011, 'Using tourism free-choice learning experiences to promote environmentally sustainable behaviour: the role of post-visit "action resources"', Environmental Education Research, vol. 17, no. 2, pp. 201-215.

Bennett, AF \& Saunders, DA 2010, 'Habitat fragmentation and landscape change: an ecological and conservation synthesis', in NS Sodhi \& PR Ehrlich (eds.), Conservation biology for all, Oxford University Press, Oxford, pp. 88-106.

Berkes, F 2004, 'Rethinking community-based conservation', Conservation Biology, vol. 18 , no. 3, pp. $621-630$

Bernardini, C \& Irvine, KN 2007, 'The "nature" of urban sustainability: private or public greenspaces?', in AG Kungolos, CA Brebbia, \& E Beriatos (eds.), Sustainable development and planning III, WIT transactions on ecology and the environment, vol. 102, WIT Press, Southampton, UK, pp. 661-674.

Bhatti, M \& Church, A 2004, 'Home, the culture of nature and meanings of gardens in late modernity', Housing Studies, vol. 19, no. 1, pp. 37-51

Bryman, A 2012, Social research methods, 4th ed., Oxford University Press, Oxford.

Carter, RW (Bill) \& Ross, H 2012, 'Are we ready to embrace stewardship?', Australasian Journal of Environmental Management, vol. 19, no. 4, pp. 207-212.

Chaskin, RJ 2001, 'Building community capacity: a definitional framework and case studies from a comprehensive community initiative', Urban Affairs Review, vol. 36, no. 3, pp. 291-323. 
Chawla, L \& Cushing, DF 2007, 'Education for strategic environmental behavior', Environmental Education Research, vol. 13, no. 4, pp. 437-452.

Clayton, S 2007, 'Domesticated nature: motivations for gardening and perceptions of environmental impact', Journal of Environmental Psychology, vol. 27, no. 3, pp. 215-224.

Cook, EM, Hall, SJ \& Larson, KL 2012, 'Residential landscapes as social-ecological systems: a synthesis of multi-scalar interactions between people and their home environment', Urban Ecosystems, vol. 15, no. 1, pp. 19-52.

Cosquer, A, Raymond, R \& Prevot-Julliard, A-C 2012, 'Observations of everyday biodiversity: a new perspective for conservation?', Ecology and Society, vol. 17, no. 4 , art2.

Davidson, S 2012, 'Up-scaling social behaviour change programmes: the case of ecoteams', in L Whitmarsh, I Lorenzoni \& S O'Neill (eds.), Engaging the public with climate change: behaviour change and communication, Taylor and Francis, Hoboken, NJ, pp. 180-199.

Davies, ZG, Fuller, RA, Loram, A, Irvine, KN, Sims, V \& Gaston, KJ 2009, 'A national scale inventory of resource provision for biodiversity within domestic gardens', Biological Conservation, vol. 142, no. 4, pp. 761-771.

Doody, BJ, Sullivan, JJ, Meurk, CD, Stewart, GH \& Perkins, HC 2009, 'Urban realities: the contribution of residential gardens to the conservation of urban forest remnants', Biodiversity and Conservation, vol. 19, no. 5, pp. 1385-1400.

Dunn, RR, Gavin MC, Sanchez, MC \& Solomon, JN 2006, 'The pigeon paradox: dependence of global conservation on urban nature', Conservation Biology, vol. 20, no. 6, pp. 1814-1816.

Ernstson, H, Barthel, S, Andersson, E \& Borgstrom, ST 2010, 'Scale-crossing brokers and network governance of urban ecosystem services: the case of Stockholm', Ecology and Society, vol. 15, no. 4, art28.

Evans, C, Abrams, E, Reitsma, R, Roux, K, Salmonsen, L \& Marra, P 2005, 'The neighborhood nestwatch program: participant outcomes of a citizen-science ecological research project', Conservation Biology, vol. 19, no. 3, pp. 589-594. 
Freeman, C, Dickinson, KJM, Porter, S \& van Heezik, Y 2012, "'My garden is an expression of me": exploring householders' relationships with their gardens', Journal of Environmental Psychology, vol. 32, no. 2, pp. 135-143.

Galbraith, JA, Beggs, JR, Jones, DN \& Stanley, MC 2015, 'Supplementary feeding restructures urban bird communities', Proceedings of the National Academy of Sciences of the United States of America, vol. 112, no. 20, pp. E2648-E2657.

Goddard, MA, Dougill, AJ \& Benton, TG 2010, 'Scaling up from gardens: biodiversity conservation in urban environments', Trends in Ecology \& Evolution, vol. 25, no. 2, pp. 90-98.

Goddard, MA, Dougill, AJ \& Benton, TG 2013, 'Why garden for wildlife? Social and ecological drivers, motivations and barriers for biodiversity management in residential landscapes', Ecological Economics, vol. 86, pp. 258-273.

Guest, G, Bunce, A \& Johnson, L 2006, 'How many interviews are enough?: an experiment with data saturation and variability', Field Methods, vol. 18, no. 1, pp. 59-82.

van Heezik, YM, Dickinson, KJM \& Freeman, C 2012, 'Closing the gap: communicating to change gardening practices in support of native biodiversity in urban private gardens', Ecology and Society, vol. 17, no. 1, art34.

Ignatieva, M \& Stewart, G 2009, 'Homogeneity of urban biotopes and similarity of landscape design language in former colonial cities', in MJ McDonnell, AK Hahs \& $\mathrm{JH}$ Breuste (eds.), Ecology of cities and towns: a comparative approach, Cambridge University Press, New York, pp. 399-421.

Ikin, K, Knight E, Lindenmayer, DB, Fischer, J \& Manning AD 2013, 'The influence of native versus exotic streetscape vegetation on the spatial distribution of birds in suburbs and reserves', Diversity and Distributions, vol. 19, no. 3, pp. 294-306.

Kendal, D, Williams, KJH \& Williams, NSG 2012, 'Plant traits link people's plant preferences to the composition of their gardens', Landscape and Urban Planning, vol. 105, pp. 34-42.

Kirkpatrick, J, Daniels, G \& Davison, A 2009, 'An antipodean test of spatial contagion in front garden character', Landscape and Urban Planning, vol. 93, no. 2, pp. 103-110. 
Knox City Council 2016, Gardens for Wildlife, viewed 9 October 2016 $<w w w . k n o x . v i c . g o v . a u / g 4 w>$.

Knox City Council \& Knox Environment Society 2008, Gardens for Wildlife, pamphlet printed by Knox City Council, Victoria, Australia.

Kowarik, I 2011, 'Novel urban ecosystems, biodiversity, and conservation', Environmental Pollution, vol. 159, pp. 1974-1983.

Lambin, EF, Turner, BL, Geist, HJ, Agbola, SB, Angelsen, A, Bruce, JW, Coomes, OT, Dirzo, R, Fischer, G, Folke, C, George, PS, Homewood, K, Imbernon, J, Leemans, R, Li, X, Moran, EF, Mortimore, M, Ramakrishnan, PS, Richards, JF, Skånes, H, Steffen, W, Stone, GD, Svedin, U, Veldkamp, TA, Vogel, C \& Xu, J 2001, 'The causes of land-use and land-cover change: moving beyond the myths', Global Environmental Change, vol. 11, no. 4, pp. 261-269.

Larson, KL, Cook, E, Strawhacker, C \& Hall, SJ 2010, 'The influence of diverse values, ecological structure, and geographic context on residents' multifaceted landscaping decisions', Human Ecology, vol. 38, no. 6, pp. 747-761.

Lerman, SB, Turner, VK \& Bang, C 2012, 'Homeowner associations as a vehicle for promoting native urban biodiversity', Ecology and Society, vol. 17, no. 4, art 45.

Lindemann-Matthies, P \& Marty, T 2013, 'Does ecological gardening increase species richness and aesthetic quality of a garden?', Biological Conservation, vol. 159, pp. $37-44$.

Lorimer, GS 2010, Sites of biological significance in Knox, vol. 1, 2nd ed., A Report to Knox City Council.

McCaffrey, RE \& Mannan, RW 2012, 'How scale influences birds' responses to habitat features in urban residential areas', Landscape and Urban Planning, vol. 105, no. 3, pp. 274-280.

Nilon, $\mathrm{CH}$ 2010, 'Urban biodiversity and the importance of management and conservation', Landscape and Ecological Engineering, vol. 7, no. 1, pp. 45-52.

Nisbet, EK, Zelenski, JM \& Murphy, SA 2009, 'The nature relatedness scale: linking individuals' connection with nature to environmental concern and behavior', Environment and Behavior, vol. 41, no. 5, pp. 715-740.

Norton, BG 2005, Sustainability: a philosophy of adaptive ecosystem management, The University of Chicago Press, Chicago. 
Oskamp, S 2002, 'Summarizing sustainability issues and research approaches', in $P$ Schmuck \& PW Schultz (eds.), Psychology of sustainable development, Kluwer Academic Publishers, Boston, pp. 301-324.

Pannell, DJ, Marshall, GR, Barr, N, Curtis, A, Vanclay, F \& Wilkinson, R 2006, 'Understanding and promoting adoption of conservation practices by rural landholders', Australian Journal of Experimental Agriculture, vol. 46, no. 11, pp. 1407-1424.

Power, ER 2005, 'Human-nature relations in suburban gardens', Australian Geographer, vol. 36, no. 1, pp. 39-53.

Pyle, RM 2003, 'Nature matrix: reconnecting people and nature', Oryx, vol. 37, no. 2, pp. 206-214.

Race, D, Curtis, A \& Sample, R 2012, 'Restoring the bush on private land: perspectives of landholders in Victoria', Australasian Journal of Environmental Management, vol. 19, no. 4, pp. 227-240.

van der Ree, R 2009, 'The ecology of roads in urban and urbanising landscapes', in MJ McDonnell, AK Hahs \& JH Breuste (eds.), Ecology of cities and towns: a comparative approach, Cambridge University Press, New York, pp. 185-196.

Robinson, L \& Glanznig, A 2003, Enabling ecoaction: a handbook for anyone working with the public on conservation, Humane Society International, WWF Australia, World Conservation Union, Sydney.

Rudd, H, Vala, J \& Schaefer, V 2002, 'Importance of backyard habitat in a comprehensive biodiversity conservation strategy: a connectivity analysis of urban green spaces', Restoration Ecology, vol. 10, no. 2, pp. 368-375.

Schwartz, MW 2006, 'How conservation scientists can help develop social capital for biodiversity', Conservation Biology, vol. 20, no. 5, pp. 1550-1552.

Secretariat of the Convention on Biological Diversity 2012, Cities and biodiversity outlook, Montreal.

Selinske, MJ, Coetzee, J, Purnell, K, Knight, AT \& Lombard AT 2015, 'Understanding the motivations, satisfaction, and retention of landowners in private land conservation programs', Conservation Letters, vol. 8, no. 4, pp. 282-289.

Shaw, A, Miller, K \& Wescott, G 2013, 'Wildlife gardening and connectedness to nature: engaging the unengaged', Environmental Values, vol. 22, no. 4, pp. 483-502. 
Shwartz, A, Turbé, A, Simon, L \& Julliard, R 2014, 'Outstanding challenges for urban conservation research and action', Global Environmental Change, vol. 28, pp. 39-49.

Smith, RM, Thompson, K, Hodgson, JG, Warren, PH \& Gaston, KJ 2006, 'Urban domestic gardens (ix): composition and richness of the vascular plant flora, and implications for native biodiversity', Biological Conservation, vol. 129, no. 3, pp. 312-322.

Snep, RP, Kooijmans, JL, Kwak, RG, Foppen, RP, Parsons, H, Awasthy, M, Sierdsema, HLK, Marzluff, JM, Fernandez-Juricic, E, de Laet, J \& van Heezik, YM 2016, 'Urban bird conservation: presenting stakeholder-specific arguments for the development of bird-friendly cities', Urban Ecosystems, vol. 19, no. 4, pp. 1535-1550.

Standish, RJ, Hobbs, RJ \& Miller, JR 2013, 'Improving city life: options for ecological restoration in urban landscapes and how these might influence interactions between people and nature', Landscape Ecology, vol. 28, no. 6, pp. 1213-1221.

Steg, L \& Vlek, C 2009, 'Encouraging pro-environmental behaviour: an integrative review and research agenda', Journal of Environmental Psychology, vol. 29, no. 3, pp. 309-317.

Thornberg, R \& Charmaz, K 2011, 'Grounded theory', in SD Lapan, MT Quartaroli \& FJ Riemer (eds.), Qualitative research: an introduction to methods and designs, Wiley, Hoboken, NJ, pp. 41-67.

Threlfall, CG, Williams, NS, Hahs, AK \& Livesley, SJ 2016, 'Approaches to urban vegetation management and the impacts on urban bird and bat assemblages', Landscape and Urban Planning, vol. 153, pp. 28-39.

Uren, HV, Dzidic, PL \& Bishop, BJ 2015, 'Exploring social and cultural norms to promote ecologically sensitive residential garden design', Landscape and Urban Planning, vol. 137, pp. 76-84.

Werner, CM 1999, 'Psychological perspectives on sustainability', in E Becker \& T Jahn (eds.), Sustainability and the social sciences: a cross-disciplinary approach to integrating environmental considerations into theoretical reorientation, Zed Books, New York, pp. 223-242. 
White, JG, Fitzimons, JA, Palmer, GC \& Antos, MJ 2009, 'Surviving urbanisation: maintaining bird species diversity in urban Melbourne', The Victorian Naturalist, vol. 126 , no. 3, pp. 73-78.

Yin, RK 2003, Case study research: design and methods, 3rd ed., Sage Publications, Thousand Oaks, CA. 
Table 1. Characteristics of interviewees: demographic, property, and G4W membership.

\begin{tabular}{|c|c|c|c|c|c|c|}
\hline Gender & Male: & 9 & Female: & 7 & Total: & 16 \\
\hline Qualifications & High School: & 8 & Certification: & 1 & Tertiary/plus: & 7 \\
\hline Country of origin & Australia: & 12 & Europe: & 3 & SE Asia: & 1 \\
\hline Employment & Full time: & 8 & Part time: & 3 & Retired: & 5 \\
\hline Location & 7 postcodes repr & sented & & & & \\
\hline \multirow[t]{3}{*}{ Age $^{*}$} & $<25$ : & 1 & 55-64: & 4 & & \\
\hline & 35-44: & 4 & 65-74: & 2 & & \\
\hline & $45-54$ & 3 & $75+$ & 1 & & \\
\hline \multirow[t]{5}{*}{ Lot size (sqm) } & <1000sqm: & 6 & & & & \\
\hline & 1000-1999sgm: & 4 & & & & \\
\hline & 2000-2999sqm: & 3 & & & & \\
\hline & 3000-3999sqm: & 2 & & & & \\
\hline & 23,000sqm: & 1 & & & & \\
\hline \multirow[t]{3}{*}{ Years at address } & $1 \mathrm{yr}:$ & 1 & 18-21 yrs: & 3 & & \\
\hline & 2-5 yrs: & 6 & 25-26 yrs: & 2 & & \\
\hline & 8 yrs: & 2 & 40 yrs: & 2 & & \\
\hline \multirow[t]{3}{*}{ Years as member } & $<.5$ yr: & 2 & 4.5-5.5 yrs: & 2 & & \\
\hline & $.5-1.5$ yrs: & 3 & 5.5-6.5 yrs: & 3 & & \\
\hline & 2.5-3.5 yrs: & 5 & 7.5-8.5 yrs: & 1 & & \\
\hline
\end{tabular}

* One participant did not provide an age category 


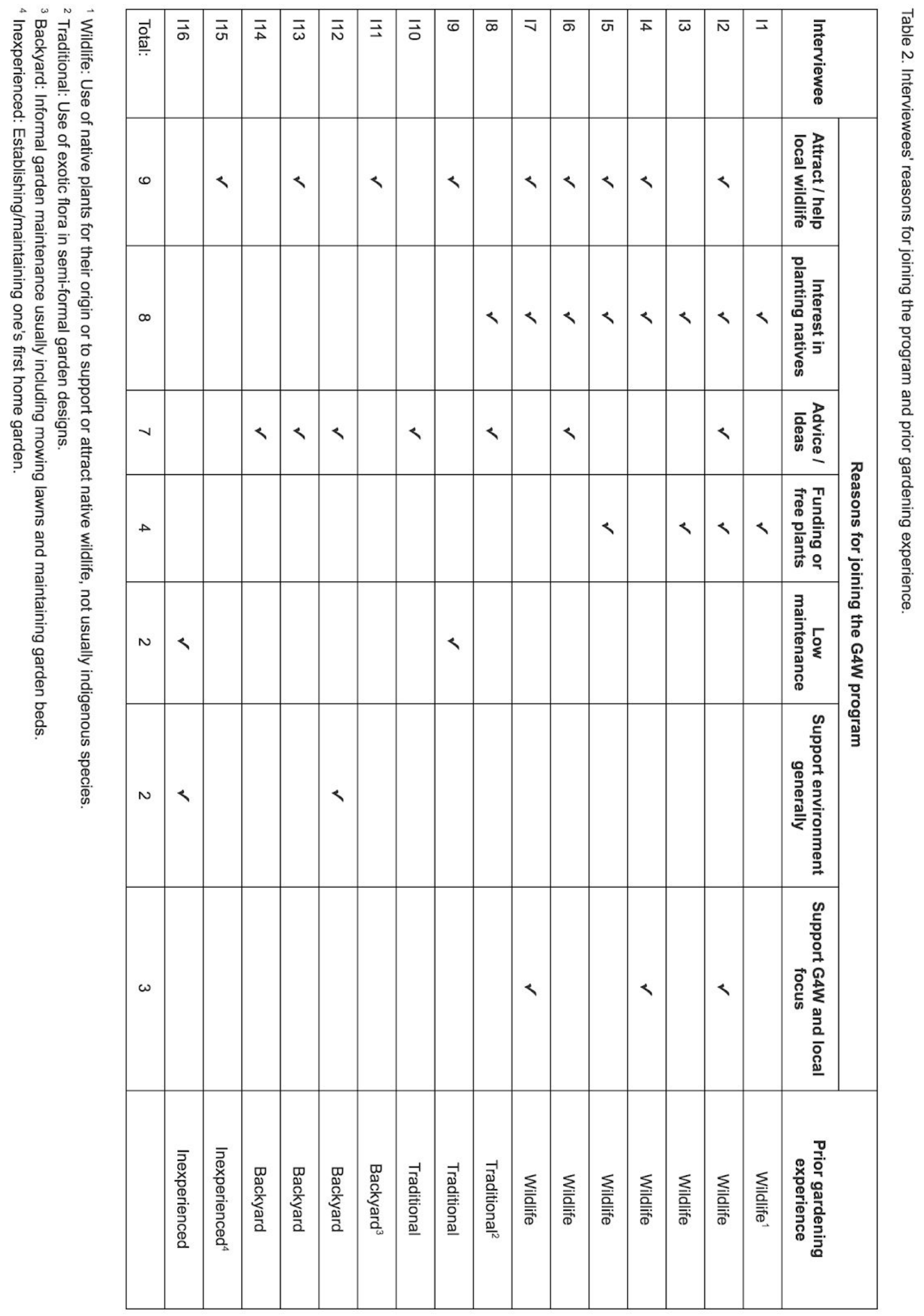




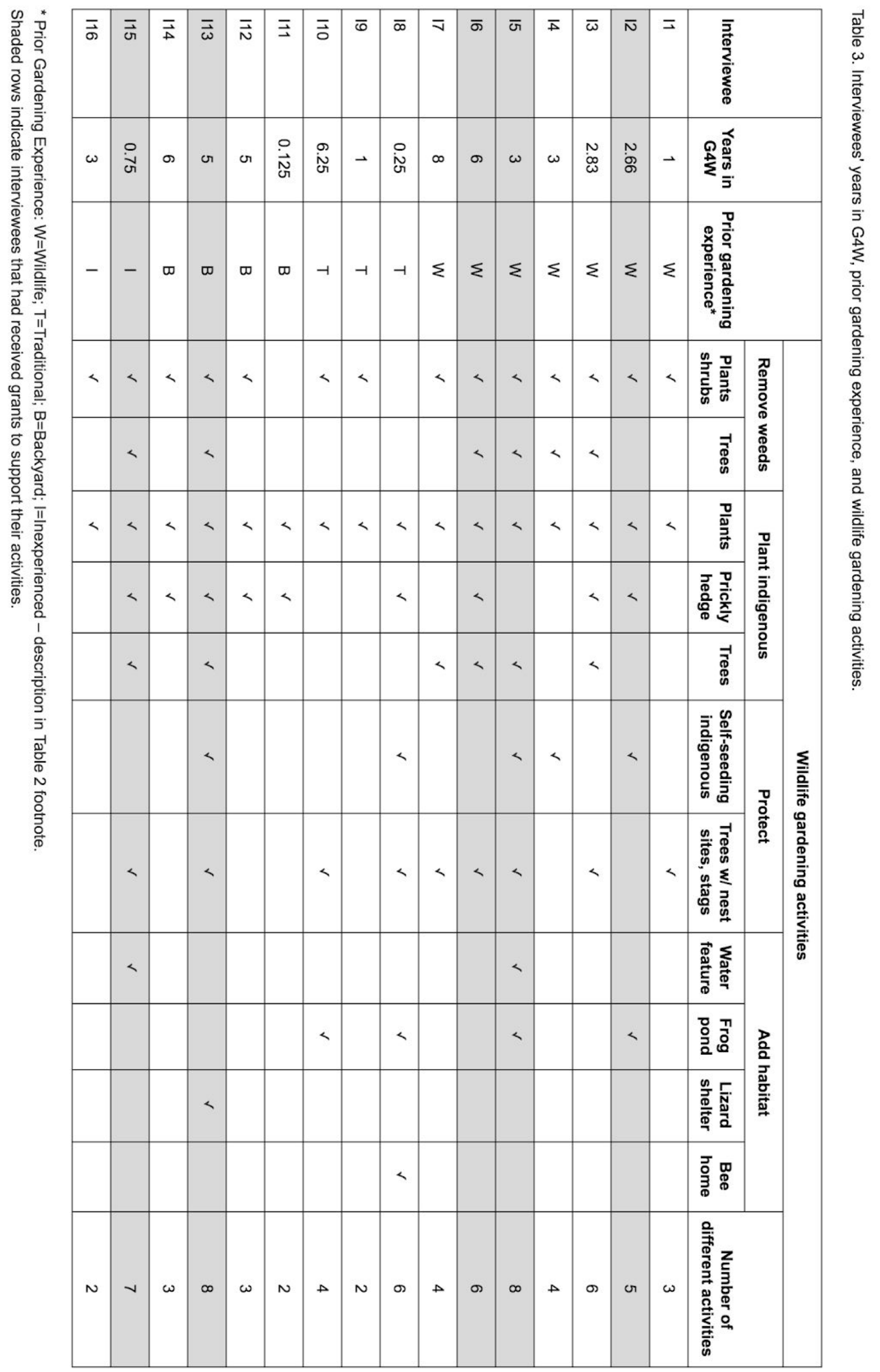

